\title{
The Relationship Between the BCL1 Variant of the Glucocorticoid Receptor Gene and Non-Syndromic Microtia
}

\section{Sendromik Olmayan Microtia ve Glucocorticoid Receptor Genindeki BCL1 Variantının İlişkisi}

\author{
Ayşe Feyda Nursal $^{1}$ (D), Kürşat Özdilli² (D), Mehmet Bekerecioğlu ${ }^{3}$ (D), Berker Büyükgüral ${ }^{4}$ (D), \\ Sacide Pehlivan ${ }^{5}$ (D)
}

\footnotetext{
${ }^{1}$ Hitit University, Faculty of Medicine, Department of Medical Genetics, Çorum, Turkey

2 Medipol University, Faculty of Medicine, Department of Medical Biology, Istanbul, Turkey

3 Kahramanmaras Sütçü İmam University, Faculty of Medicine, Department of Plastic, Reconstructive \& Aesthetic Surgery, Kahramanmaras, Turkey

${ }_{4}^{4}$ Private Clinic for Plastic, Reconstructive \& Aesthetic Surgery, Istanbul, Turkey

${ }^{5}$ Istanbul University, Istanbul Faculty of Medicine, Department of Medical Biology, Istanbul, Turkey
}

ORCID: A.F.N. 0000-0001-7639-1122; K.Ö. 0000-0002-7129-5024; B.B. $0000-0002-2422-7272$; B.B. $0000-0002-3308-8614$; S.P. $0000-0003-1272-5845$

\section{Corresponding author/Sorumlu yazar:} Sacide Pehlivan

Istanbul University, Istanbul Faculty of Medicine, Department of Medical Biology, Istanbul,Turkey E-mail: sacide.pehlivan@istanbul.edu.tr, psacide@hotmail.com

Submitted/Gelis tarihi: 27.08 .2020 Accepted/Kabul Tarihi: 14.10.2020

Citation/Atıf: Nursal AF, Ozdilli K, Bekerecioglu M, Buyukgural B, Pehlivan S. The relationship between the $B C L 1$ variant of the glucocorticoid receptor gene and non-syndromic microtia. Sağlık Bilimlerinde İleri Araştırmalar Dergisi 2020; 3(3): 168-172

https://doi.org/10.26650/JARHS2020-786359

\section{ABSTRACT}

Objective: Microtia is defined as a congenitally defective external ear which has different degrees of severity from a simple isolated reduced size to complete loss of the ear. Normal fetal development is affected by the Glucocorticoids (GCs), which are critical for the maturation and development of different fetal tissues. The glucocorticoid receptors (GR) influence the GCs' actions. Therefore, we aimed to evaluate the association between the NR3C1 (encoding GR) gene BCL1 variant and its role in the development of non-syndromic microtia.

Materials and Methods: Nineteen cases with microtia and forty healthy controls enrolled in the present study. We genotyped the NR3C1 BCL1 variant using the polymerase chain reaction (PCR) and PCR-restriction fragment length polymorphism (RFLP) method. The patients and controls were compared in terms of allele and genotype distribution using the $\chi^{2}$ test.

Results: No statistical association was found between the NR3C1 BCL1 genotype distribution and microtia risk. However, the NR3C1 BCL1 variant G allele was lower in patients than in the healthy controls ( $\mathrm{p}=0.034$, OR:2.411,95\%Cl: 1.115-5.212). In the current study, our results suggested that the subjects carrying the G allele in the NR3C1 gene BCL1 variant had a lower risk of microtia.

Conclusion: Further studies are needed to determine whether this gene variant has a role in the risk of developing the disorder.

Keywords: Microtia, DNA, glucocorticoid receptor, BCL1, variant

\section{Öz}

Amaç: Microtia, basit izole küçük boyuttan tamamen kulak kaybına kadar farklı şiddet derecelerine sahip, kongenital kusurlu bir dış kulak olarak tanımlanır. Normal fetal gelişim, farklı fetal dokuların olgunlaşması ve gelişimi için kritik olan Glukokortikoidlerden (GK) etkilenir. Glukokortikoid reseptörleri (GR), GC'lerin fonksiyonlarını etkiler. Bu nedenle NR3C1 gen (GR kodlayan) BCL1 varyantı ile sendromik olmayan mikrotia gelişmesindeki rolü arasındaki ilişkiyi değerlendirmeyi amaçladık.

Gereç ve Yöntem: Bu çalışmaya ondokuz mikrotia olgusu ve kırk sağlıklı kontrol dahil edildi. NR3C1 BCL1 varyantı polimeraz zincir reaksiyonu (PZR) ve sınırlayıcı parça uzunluk poliorfizmi (RFLP) yöntemini kullanarak genotipledik. Hastalar ve kontroller $\chi^{2}$ testi kullanılarak alel ve genotip dağılımı açısından karşılaştırıldı.

Bulgular: NR3C1 BCL1 genotip dağılımı ve mikrotia arasında istatistiksel bir ilişki bulunmadı. Bununla birlikte, NR3C1 BCL1 varyant G aleli hastalarda sağlıklı kontrollere göre daha düşüktü ( $p=0.034$, OR:2.411, 95\%Cl: 1.115-5.212). Bu çalışmada, sonuçlarımız NR3C1 gen BCL1 varyantı G aleli taşıyan kişilerin daha düşük bir mikrotia riskine sahip olduğunu gösterdi.

Sonuç: $\mathrm{Bu}$ gen varyantının, bozukluk riskinin gelişmesinde bir rolü olup olmadığını belirlemek için daha fazla çalıșmaya ihtiyaç vardır.

Anahtar Kelimeler: Microtia, DNA, glukokortikoid reseptör, BCL1, varyant 


\section{INTRODUCTION}

Microtia is a congenitally defective external ear which has different degrees of severity from a single isolated reduced size to complete loss of the ear (1). In microtia, there are disorganized remnants of cartilage that are attached to a varying amount of lobule tissue, which is often moved from a symmetrical position with the contralateral ear (1). The reason for microtia is part of a spectrum of a syndrome or anomalies or an isolated condition. According to the population-based studies which were conducted on microtia prevalence in France, Sweden, Italy, United States, and Finland, it was shown that prevalence rates ranged from 0.83 to 4.34 for every 10,000 births (2). There are different genetic causes for microtia in both humans and animal models, helping us understand the condition and leading to the identification of a common cause for the condition.

Stress responses are mediated by Glucocorticoids (GCs), which are the steroid hormones produced mainly by the adrenal glands. Pharmacological GC excess plays a more nuanced role in the biology of the response to stress. It has balanced homeostatic effects facilitating short-time recovery and survival from the challenge while their chronic and acute effects are recognized well (3). GCs are also effective in the development of normal fetuses leading to the maturation and development of different fetal tissues such as the gut, skeletal muscle, adipous tissue, the liver, and lungs and preparedness for extrauterine life (4). The nuclear receptor protein, known as glucocorticoid receptors (GR), is due to the actions of GCs. The NR3C1 (nuclear receptor subfamily 3 , group $C$, member 1 ) gene, which is located on chromosome 5 , is used to encode GRs. There are three domains for the structure of this gene: DNA-binding domain, carboxy-terminal ligand binding, and amino transactivation domain. When the form of the GR is unliganded, it is located in the cytoplasm as large complex protein, and its binding to cortisol causes its dissociation and a conformational change, translocating the GR receptor to the nucleus in which it regulates the transcription of GR gene as a transcription factor through several mechanisms (5). There was a biallelic polymorphism identifiable downstream of the exon 2-intron 2 junction NR3C1 gene. The processing of GCR primary transcripts might be affected by the polymorphism, increasing the sensitivity of GC (6).

Therefore, we performed a case-control analysis of the association between the NR3C1 BCL1 variant and non-syndromic microtia.

\section{MATERIAL AND METHODS}

\section{Study Population}

The study group consisted of 19 subjects with microtia and 40 unrelated healthy control subjects. The subjects with microtia were recruited from those who were treated and followed-up in the Plastic, Reconstructive, and Aesthetic Surgery Department, Kahraman Sutcu Imam University, Kahramanmaras, Turkey. Syndromic patients were excluded from the study. The healthy control group was recruited from the patients living in the same geographical areas, and they were well-matched with the patient group in terms of gender and age. The controls had no personal or family history of dysmorphic disorders. All subjects, patients, and controls were of Turkish origin. Informed written consent was obtained from all patients and subjects before enrollment to the study, according to the ethical guidelines of the $2008 \mathrm{Dec}$ laration of Helsinki. Ethical approval was obtained from the Local Human Research Ethics Committee.

\section{Genotyping}

Blood samples were obtained from all subjects. Genomic DNA was extracted from mononuclear cells obtained from ethylenediaminetetraacetic acid (EDTA)- treated peripheral venous blood using the salting-out method (7). The distribution of the NR3C1 BCL1 variant in the intron 2 was evaluated in the non-syndromic microtia patients and healthy controls by using the polymerase chain reaction-restriction fragment length polymorphism (PCR-RFLP) method as described previously (8).

\section{Statistical Analysis}

Statistical analysis was performed using the software SPSS version 20.0 for Windows (SPSS Inc., Chi- 
cago, IL, USA). The statistical significance of the differences among the groups was estimated using logistic regression analysis. Odds ratio (OR) and 95\% confidence interval (CI) were also calculated. Differences in the genotype distribution between the two groups were compared with the chi-square test and, when needed, Fisher's exact test was used. The level of significance was set at $\mathrm{p} \leq 0.05$.

\section{RESULTS}

Genotype distributions and allele frequencies of the NR3C1 BCL1 variant are presented in Table 1. There was no significant difference between the patients and controls in terms of the genotype distribution of the NR3C1 BCL1 variant ( $\mathrm{p}>0.05)$. The NR3C1 BCL1 variant $G$ allele was lower in patients compared to healthy controls ( $p=0.034$, OR:2.411, 95\%Cl: 1.115-5.212). The genotype distribution of the NR3C1 BCL1 variant in the patients and controls was compatible with HWE.

\section{DISCUSSION}

Microtia may be exhibited alone, or alongside other abnormalities, mainly occurring in bilateral cases. Eyelid defects, renal abnormalities, cardiac defects, facial asymmetry, oral clefts, vertebral deformities, and polydactyly are among the most common associated malformations (9). Despite the causes of microtia and the related syndromes being poorly understood, their is strong evidence that shows that environmental and genetic components are effective. There have been different familial cases with Mendelian modes of inheritance (9). Several studies on animal models suggest that microtia is caused by particular genetic pathways. Microtia is caused by the mouse models, which demonstrate that mutations in eyes have absent (EYA), IRF6, TBX1, and CHUK and specific genes HOXA2, SIX (10).

The placenta is a source of gas exchange, excretion, fetal nutrients, water, and immune regulation. Growth factors, simultaneous production of several hormones related to pregnancy, proteins, and also an array of neuropeptide hormones, analogous to those which are produced by the pituitary of the brain, and hypothalamus including, $\mathrm{CRH}$, TRH, GHRH, GnRH, and oxytocin cause these effects (11). GCs as the steroid hormones are secreted from the adrenal glands, which are necessary for maintaining the stress-related and basal homeostasis as the end products of the stress-responsive HPA axis (12). There are several physiological processes in which they are involved, including electrolyte and water balance, growth, the immune response, cardiovascular function, cognitive and mood functions, metabolism, reproduction, and development (12). Actions of GCs at the cellular level are mediated by the NR3C1 which is an intracellular receptor protein belonging to the orphan/sterol/ thyroid/ receptor/ steroidretinoid superfamily of nuclear transactivating factors which generally have more than 200 members and more than 40 members in mammals which are presently characterized and cloned among the species (13). According to Bromer et al., neurodevelopment with a lifelong effect on mental health and neurobehavioral outcomes is affected by epigenetic alteration of the NR3C1 gene in the placentas of infants, which are genetically susceptible (11). There are several polymorphic sites in the NR3C1 gene. Intron 2 of the NR3C1 gene is the place where the polymorphism BCL1 (rs41423247) is

Table 1. Genotype and allele distribution of NR3C1 BCL1 variant

\begin{tabular}{|l|c|c|c|c|c|}
\hline NR3C1 BCL1 & Patients & Controls & OR Exp (B) & 95\% CI & p \\
\hline Genotypes & $\mathrm{n}=18(\%)$ & $\mathrm{n}=70(\%)$ & & & $0.052^{*}$ \\
\hline GG & $4(22.2)$ & $4(5.7)$ & $4.714^{*}$ & $1.051-21.151^{*}$ & $0.785^{*}$ \\
\hline GC & $7(38.9)$ & $24(34.3)$ & $1.220^{*}$ & $0.419-3.550^{*}$ & $0.120^{\&}$ \\
\hline CC & $7(38.9)$ & $42(60)$ & $0.424^{\&}$ & $0.147-1.126^{\&}$ & \\
\hline Alleles & & & & \\
G & $15(58.3)$ & $32(77.1)$ & & & $0.034^{\&}$ \\
\hline C & $21(76.7)$ & $108(80.8)$ & $2.411^{\&}$ & $1.115-5.212^{\&}$ & \\
\hline
\end{tabular}

${ }^{\&}$ Fisher's Exact Test. 
located. It is localized in its transcript at position $1184+646$. Exons 2 and 3 of the NR3C1 gene are the places where intron 2 (B) is situated. The result is the substitution of $\mathrm{C}>\mathrm{G}$ in the promoter region. The BCLI variant is located at 646 nucleotides, which are above exon 2 of the $N R 3 C 1$ gene, which is correlated with the enhanced sensitivity of glucocorticoid and higher levels of cortisol (6). It has been observed that BCL1 high-function $(G)$ allele carriers show a reduction of cortisol responses after the psychosocial stressors (14). The single-nucleotide polymorphism (SNP) directly affects the $\mathrm{NR} 3 \mathrm{Cl}$ gene expression as the mechanism for the NR3C1 BCL1 variant, which enhances the sensitivity of GCs ' negative feedback mechanism. The polymorphism may be in linkage disequilibrium, altering the transcriptional activity of target genes involved in the homeostasis of insulin and glucose (15). It was reported that the NR3C1 BCL1 variant was associated with increased abdominal fat mass, and low bone mineral density $(16,17)$.

In this study, we investigated the association between the NR3C1 BCL1 variant and microtia risk. To our knowledge, this is the first study to evaluate the NRC3C1 BCL1 variant in Turkish patients with microtia. We found no association between the patients and controls in our samples in terms of the genotype distribution of NRC3C1 BCL1. However, the subjects carrying the $\mathrm{G}$ allele in the NR3C1 gene BCL1 variant had a lower risk of microtia. Our study had some limitations. One limitation was the relatively small sample size. Another limitation was that we tested only the BCL1 variant for the NR3C1 gene.

\section{CONCLUSION}

In conclusion, this case-control study revealed no statistically significant association between the NR3C1 BCL1 variant and microtia in a Turkish cohort. However, the NR3C1 BCL1 variant G allele may have a protective role against microtia. Further studies are needed to determine whether this gene variant is effective in the development of the risk of disorder.

Hakem Değerlendirmesi: Dış bağımsız.

Peer Review: Externally peer-reviewed.
Etik Komite Onayı: Bu çalışma için etik komite onayı Yerel İnsan Araştırmaları Etik Kurulu’ndan alınmıştır.

Ethics Committee Approval: This study was approved by the Local Human Research Ethics Committee.

Bilgilendirilmiş Onam: Katılımcılardan bilgilendirilmiş onam alınmıştır.

Informed Consent: Written consent was obtained from the participants.

Yazar Katkıları: Çalışma Konsepti/Tasarım- S.P., M.B., B.B.; Veri Analizi/Yorumlama- S.P., A.F.N., K.Ö.; Yazı Taslağı- A.F.N., S.P.; İçeriğin Eleştirel İncelemesiM.B., K.Ö., B.B.; Son Onay ve Sorumluluk- A.F.N., K.Ö., M.B., B.B., S.P.; Malzeme ve Teknik Destek- K.Ö., M.B., B.B.; Süpervizyon- A.F.N., S.P., M.B.

Author Contributions: Conception/Design of Study- S.P., M.B., B.B.; Data Analysis/InterpretationS.P., A.F.N., K.Ö.; Drafting Manuscript-A.F.N., S.P.; Critical Revision of Manuscript- M.B., K.Ö., B.B.; Final Approval and Accountability- A.F.N., K.Ö., M.B., B.B., S.P.; Technical or Material Support-K.Ö., M.B., B.B.; Supervision- A.F.N., S.P., M.B.

Çıkar Çatışması: Yazarlar çıkar çatışması beyan etmemişlerdir

Conflict of Interest: Authors declared no conflict of interest.

Finansal Destek: Yazarlar finansal destek beyan etmemişlerdir.

Financial Disclosure: Authors declared no financial support.

\section{REFERENCES}

1. Alasti F, Van Camp G. Genetics of Microtia and Associated Syndromes. J Med Genet. 2009;46(6): 361-69.

2. Luquetti DV, Heike CL, Hing AV, Cunningham ML, Cox TC. Microtia: Epidemiology \& Genetics. Am J Med Genet A. 2012;158A(1): 124-39.

3. McEwen BS. Physiology and neurobiology of stress and adaptation: central role of the brain. Physiol Rev. 2007;87(3):873-904.

4. Korgun ET, Ozmen A, Unek G, Mendilcioglu I. The Effects of Glucocorticoids on Fetal 
and Placental Development. X Qian (Ed.), Glucocorticoids - New Recognition of Our Familiar Friend, InTech, Croatia 2012; 305-36.

5. El-Fayoumi R, Hagras M, Abozenadaha A, Bawazir W, Shinawi T. Association Between NR3C1 Gene Polymorphisms and Toxicity Induced by Glucocorticoids Therapy in Saudi Children with Acute Lymphoblastic Leukemia. Asian Pac J Cancer Prev. 2018; 19(5): 1415-23.

6. Fleury I, Beaulieu P, Primeau M, Labuda D, Sinnett D, Krajinovic M. Characterization of the BclI polymorphism in the glucocorticoid receptor gene. Clin Chem. 2003;49:1528-31.

7. Miller SA, Dykes DD, Polesky HF. A simple salting out procedure for extracting DNA from human nucleated cells. Nucleic Acids Res. 1988;16:1215.

8. Aydeniz A, Sever T, Pehlivan S, Pehlivan M, Altındag O, Budeyri S, Gursoy S. Investigation of Glucocorticoid Receptor Gene Bcl-1 Polymorphism in Rheumatoid Arthritis. Turk J Rheumatol 2011;26(3):199-203.

9. Ruimin Qiao, Yuyong He, Bo Pan, Shijun Xiao, Xufei Zhang, Jing Li, Zhiyan Zhang, Yuan Hong, Understanding the molecular mechanisms of human microtia via a pig model of HOXA1 syndrom. Disease Models \& Mechanisms 2015;8:611-22.

10. Gendron C, Schwentker A, van Aalst JA. Genetic Advances in the Understanding of Microtia. J Pediatr Genet. 2016; 5(4):189-97.

11. Bromer C, Marsit CJ, Armstrong DA, Padbury JF, Lester B. Genetic and epigenetic variation of the glucocorticoid receptor (NR3C1) in placenta and infant neurobehavior. Developmental Psychobiology 2013;55(7):673-83.

12. Timmermans S, Souffriau J, Libert C. A General Introduction to Glucocorticoid Biology. Front Immunol. 2019;10:1545.

13. Mangelsdorf DJ, Thummel C, Beato M, Herrlich P, Schütz G, Umesono K, Blumberg B, Kastner P, Mark M. The nuclear receptor superfamily: the second decade. Cell. 1995; 83:835-39.

14. Wust S, Federenko IS, van Rossum EF, Koper JW, Kumsta R, Entringer S, Hellhammer DH. A psychobiological perspective on genetic determinants of hypothalamus-pituitary-adrenal axis activity. Ann N Y Acad Sci. 2004;1032:52-62.

15. Srivastava N, Prakash J, Lakhan R, Agarwal CG, Pant DC, Mittal B. Influence of Bcl-1 Gene Polymorphism of Glucocorticoid Receptor Gene (NR3C1, rs41423247) on Blood Pressure, Glucose in Northern Indians. Indian J Clin Biochem. 2011;26(2):125-30.

16. van Rossum EF, Koper JW, van den Beld AW, Uitterlinden AG, Arp P, Ester W, et al. Identification of the BclI polymorphism in the glucocorticoid receptor gene: association with sensitivity to glucocorticoids in vivo and body mass index. Clin Endocrinol (Oxf). 2003;59(5):585-92.

17. Szappanos A, Patócs A, Töke J, Boyle B, Sereg M, Majnik J, Borgulya G, Varga I, Likó I, Rácz K, Tóth M. BclI polymorphism of the glucocorticoid receptor gene is associated with decreased bone mineral density in patients with endogenous hypercortisolism. Clin Endocrinol (Oxf). 2009;71(5):636-43. 